\title{
England, Holland, and the Fishing Wars
}

\author{
Joel D. Benson \\ Northwest Missouri State University
}

\begin{abstract}
The Dutch herring trade contributed greatly to Dutch commercial prosperity. The most profitable Dutch fishing grounds, however, were off the coasts of England and Scotland. For centuries, the English allowed the Dutch to fish these waters. During the reign of James I, however, the changing English perspective of the Dutch led the English Crown to question the right of the Dutch to fish in English waters. In the fishing trade, centuries of cooperation gave way to an emerging commercial rivalry.
\end{abstract}

Keywords: fishing, herring, James I, Mare Liberum, Proclamation of 1609, Estates General

As long as the Low Countries remained a disjointed group of separate provinces, the English were unconcerned with the Dutch fishing off their coasts; as long as they acknowledged the sovereignty of the English Crown over English waters. Edward II first issued a proclamation claiming this sovereignty, and Henry V, VI, and VII all supported it (Elder 1912, 2-4). The English government did not challenge the Dutch right to fish in English waters until the reign of James I.

Commentators throughout Europe remarked on the size of the Dutch herring fleet and its contribution to Dutch economic growth after 1600. The Dutch government went as far as to call the fishery the gold mine of the republic. The size of the Dutch fishing fleet has been a matter of debate ever since the 17th century. Contemporary English and French sources insisted that the Dutch possessed a fleet of 25 thousand vessels. Even many of the less inflated estimates, however, are demonstrably incorrect. A. R. Mitchell gives figures showing 14 hundred fishing boats of various sizes in the Low Countries in 1562, while Geoffrey Parker, on the other hand, cites a survey of Dutch shipping in 1634 numbering the fishing fleet at 2,250 (Unger 1980, 254-67; Mitchell in Rich 1977, 134, 148-53; Parker 1979, 196).

Observing the prosperity of the United Provinces, the English correctly attributed at least part of it to the benefits the Dutch attained from fishing in English waters. In 1604, the House of Lords passed an act to encourage the expansion of English fishing. Unfortunately, Dutch herring boats simply outnumbered the English vessels. In October 1604, the fish merchants and fishermen of England offered to increase the taxes paid to the Crown for fish, if James would retake possession of the fisheries in English waters from the Dutch (L.J. 2: 335-8; Salisbury: 16: 329-30).

This was the first challenge to centuries of official acceptance of the Dutch presence off the English and Scottish coasts. Reacting to numerous complaints concerning foreigners fishing in English waters, the Privy Council appointed a special committee in 1606 to look into the matter. No action resulted from this investigation, but many Englishmen found it difficult to accept the advantages that accrued to the Dutch from

Joel D. Benson, professor \& chair, Department of Humanities \& Social Sciences, Northwest Missouri State University, USA; main research fields: Tudor-Stuart England, Anglo-Dutch relations in the 16th and 17th centuries, Modern Britain, Early Modern and Modern Europe. 
fishing in English waters (Lansdowne MSS 142: f.375).

The next opportunity for the English government to consider some action against Dutch fishing in English waters came in 1607 when Spain announced its willingness to open negotiations to end hostilities with the Dutch. Seeking to improve its position upon entering such negotiations, the United Provinces proposed offensive and defensive alliances with both England and France. At peace with Spain, James insisted that the question of Dutch fishing in English waters had to be addressed before he could enter into such an alliance. In a letter to the king, Sir Nicholas Hall insisted that the Dutch took fish out of his majesty's seas valued at "40 hundred thousand pounds" annually, and he proposed a tax be levied on the Dutch fishermen. Both England and France concluded limited alliances with the Dutch, but the Anglo-Dutch agreement did not address the question of Dutch fishing in English waters (C.S.P. Venice 11, passim; S.P. 14/32/30-31).

Not surprisingly, these constant complaints to the English government and the suggestion that England should check Dutch fishing off the English and Scottish coasts, provoked an adverse reaction in the United Provinces. Modern estimates of the value of Dutch fishing ranged from one to three million pounds sterling. An estimate of two million pounds sterling would place its economic value at the equivalent of the British cloth industry. This truly was a gold mine, and the English challenge to Dutch fishing rights could not go unanswered (Wilson 1968, 65-68; Wilson in Rich 1977, 4: 518-20).

That answer came from the most prominent Dutch legal mind of the time, Hugo Grotius. In 1604, the Dutch East India Company commissioned Grotius to write a legal defense of the Dutch right to trade in the East and West Indies. One chapter of De Jure Praddae (On the Law of Prize and Booty), entitled Mare Liberum (The Freedom of the Seas), defended the rights of Dutch fishermen maintaining that navigation itself was free and open to all. Grotius argued that James could regulate or tax English fishermen, but he could not claim sovereignty over international waters (Wilson 1968, 59-63; D.N.B. s.v. “Grotius, Hugo”).

James apparently decided that Mare Liberum constituted a specific delineation of Dutch policy and began formulating a response to this attack on his sovereignty. Two documents written in the spring of 1609 formed a background for James's response. The authors of both documents are unknown. The first author suggested that foreign fishermen pay a duty of one tenth of their catch to the English Crown and urged England to increase its own efforts at fishing if it hoped to compete economically with the United Provinces. The second author advised James to charge foreigners to fish in English waters; a practice which could net the English Crown, he argued, 20 thousand pounds per year. This document also urged James to imitate the Dutch and increase the English fishing industry (Lansdowne MSS 142: ff.360, 371; Elder 1912, 7).

Whether or not James saw either of these manuscripts, he was certainly aware of the arguments they presented. In May, James received yet another petition from English fishermen complaining that the Dutch drove them away from their fishing grounds and sold some of their catch in English ports, contrary to the laws of England. With this final accusation, on 6 May 1609, James issued a royal proclamation demanding that all foreign fishermen purchase a license from the English Crown before fishing in English or Scottish waters (S.P. 14/45/22-23; Lansdowne MSS 142: f.358; Larkin and Hughes 1973, 217-9).

Two letters written by Robert Cecil shed additional light on this decision. Cecil wrote that in the 13th and 14th centuries approximately one hundred Dutch ships visited English fishing grounds. Currently, however, the Dutch sent two thousand at a time (Salisbury 21: 54). This being the argument of practicality, in a second letter, Cecil put forth the legal justification. He insisted that according to civil law, kings and princes fronting upon the sea had in the past made ordinances for better regulation and had raised taxes. National jurisdiction over such 
waters, he wrote, was generally accepted to be about one hundred miles, except in the Channel which belonged entirely and rightly to England (Winwood 1725, 49-51).

On 12 June 1609, the Estates General discussed James's proclamation and resolved to send an embassy to London to protest the new requirements. Among the arguments, the Dutch insisted that the Magnus Intercursus of 1496, a commercial treaty signed between Henry VII of England and Philip IV of Burgundy, granted the inhabitants of the Low Countries the freedom to fish off the English coasts without need of licenses. They further maintained that no prince could challenge naval rights at sea farther than he could command with a cannon. After debating the issue in August, the English Privy Council reported that James would postpone enforcement of his proclamation for one year in order to hear the arguments of the Dutch embassy (S.P. 14/47/111; Edmundson 1911, 19-24).

This embassy did not arrive in London until the following spring. In the meantime, James's hesitancy fostered a number of responses in England, encouraging the king to persevere in his original decision to regulate Dutch fishing in English waters. Two documents written by Sir William Monson claimed that the Dutch had three thousand vessels involved in the fishing trade alone, employing upwards of 50 thousand men, and garnering for the Dutch $£ 1,496,000$ annually. Monson urged the government to expand the English fishing fleet and enact further legislation regulating Dutch fishing (S.P. 14/47/112, 114; D.N.B. s.v. "Monson, William").

Various people suggested ways of procuring the payment of fees if the Dutch and other foreigners refused to purchase licenses. The most common proposal called for a tax of one tenth of the catch from foreigners fishing in English waters. Another proposal recommended the creation of a joint Anglo-Dutch fishing company which would pay a certain tax to the king. Most insisted that the Dutch should not be upset by the king's decision to control his own seas. James had not completely barred them from English waters, and they could easily bear the fee (S.P. 14/48/95; Lansdowne MSS 142, ff.367-8).

Arriving in April 1610, the Dutch embassy hoped to discuss the possibility of finally concluding an Anglo-Dutch defensive alliance, and to deal with the fishing controversy. With regards to James's proclamation, the Dutch put forth their case in a memorandum, apparently written by Hugo Grotius as it followed the argument put forth in Mare Liberum. Conversely, the English claimed that the prerogative of former English kings to grant fishing rights to foreigners implied the right of James to take them away (C.S.P. Venice 11 passim; Edmundson 1911, 26-33).

While the Dutch embassy was in London, James received additional pamphlets and letters calling for England to control Dutch fishing in English waters. One of these pamphlets, Observations Touching Trade and Commerce with the Hollander, and Other Nations, probably written by John Keymer, insisted that Dutch profits from fishing in English waters significantly contributed to Dutch prosperity. The negotiators had proceeded only as far as the statement of opposing positions when news arrived of the murder of Henry IV of France. The possibility that France might ally with, instead of against, the Habsburgs meant James could not afford to antagonize the Dutch. As a result of this change in the political scene, James postponed execution of his proclamation for another two years (McCulloch 1859/1966, 3-28; Clark and Van Eysinga 1951, 35-38).

Nevertheless, English and Scottish pamphleteers continued to expose the Dutch profits from this fishing and to recommend that his majesty's kingdoms take better advantage of their resources. In 1613, William Wellwood, a professor of mathematics and law at St. Andrews, attacked Grotius's Mare Liberum, acknowledging that all peoples enjoyed freedom of the seas but insisting that local authorities could claim sovereignty over those waters close to shore. In 1614, Tobias Gentleman published England's Way to Win 
Wealth and to Employ, Ships and Mariners, in which he described the Dutch herring industry as "their principal gold mine.” He insisted that if a country as small as Holland could accomplish such things, England could as well (Alsop 1980, 171-4; Gentleman 1614, 5, 8, and passim).

The following year Robert Kayall published anonymously, The Trades Increase. Kayall argued that England should imitate the Dutch and increase their national investment in the fishing industry in order to improve shipping, mariners, and the nation's overall employment. He also lamented that in all areas of trade the United Provinces overshadowed England, calling for the English to increase their investment in the fishing industry. From this would come an increase in merchants, an increase in trade, and an increase in prosperity (Kayall 1615, 10 and passim).

Despite the ongoing complaints against Dutch fishermen in English waters, James realized that there was little he could do to enforce his proclamation if the Dutch insisted upon ignoring it. One pamphlet published in 1616 warned that the Dutch had 10 thousand sea-going vessels and could pose a serious threat to England. Although the author admitted that only 80 of these vessels were ships of war, the Dutch fishing industry brought a yearly return of two million pounds sterling and provided the foundation of their maritime strength (Arch MSS 513: f.9; Lansdowne MSS 142: f.364).

In 1617, James decided once again to demand some recognition of his sovereignty over his own seas, sending an emissary to collect a tax from the Dutch fishing vessels off the Scottish coast. The Dutch captains refused to pay this tax, seized James's agent, and took him back to the United Provinces in captivity. The English Crown demanded an explanation and reparations, and James ordered two Dutch sailors to be detained in England. The Estates General released the English agent but insisted that Dutch captains had the right to defend their vessels. James refused to release his two captured Dutch sailors, however, until the Dutch handed over for punishment the two captains who had seized his man. The Estates General did turn over these captains along with a plea for leniency, but they denied James's right to levy a tax or demand the purchase of a license to fish (Lansdowne 142: f.398; A.P.C. 35: 32324; S.P. 84/77: ff.25-26; C.S.P. Venice 15 passim; C.S.P. Charles II, 87).

The problem for James was not just a matter of national honor, but one of personal finances. In almost constant need of money at different times in his reign, James borrowed from various people in England and abroad, including the Bank of Amsterdam. The royal finances and James's inability to collect license fees introduced in 1618 a new variable into the fishing controversy. In response to a complaint from the King of Denmark, to whom James owed a considerable amount of money, James issued a proclamation forbidding Scottish fishermen from fishing off the coasts of Fair Island, an island claimed by Denmark. The Scots asked why they could not fish in Danish waters when the Dutch fished in Scottish waters. They demanded that James issued a similar proclamation concerning the Dutch, insisting that they fished in Danish waters only because the yearly presence of the Dutch in their waters drove them to it (R.P.C. Scotland 11: 328-30; Elder 1911, 9-10).

Matters stood at stand-still when the fishing season of 1618 began. That spring the States General issued a placard promising good will and proper behavior between Dutch fishermen and the Scots but reiterating their right to fish off the Scottish coast. A double convoy of naval vessels accompanied the Dutch fishing fleet, serving notice that they meant to protect that right (S.P. 84: ff.69-70; Elder 911, 9-10).

Before James could respond to the Dutch challenge, the Estates General indicated its willingness to negotiate a settlement to the fishing controversy. Grotius was one of the Dutch representatives who arrived in London, and James ordered English jurist John Selden to prepare a legal response to Grotius's Mare Liberum. 
Selden argued that the sea was not open to all men but could be the subject of private property (S.P. 14/103/94; D.N.B. s.v. "Selden, John").

English, Scottish, and Dutch representatives finally worked out an agreement. James agreed to allow the Dutch to fish in English waters, as long as they did not come within sight of land. The Dutch government, however, refused to sanction this agreement, however, and the controversy continued (R.P.C. Scotland 11 passim; S.P. 14/109/11; Elder 1911, 9-10).

Determined to put an end to this fishing question, James informed the Estates General that if the Dutch wished to fish in English or Scottish waters, they must recognize his sovereignty. In early 1621, the Estates General sent yet another commission to London to discuss Anglo-Dutch problems in the East Indies and the fishing controversy, but political realities once again intruded. The Twelve Years Truce was due to expire later that year, and the Dutch were primarily concerned with concluding a military alliance against Spain. Still determined to conclude a marriage alliance with Spain, James refused such an alliance, and by the time the Dutch representatives finally left England in 1623, no agreement had been reached on the fishing question (C.S.P. Venice 16 passim; S.P. 14/157/47-48; Elder 1911, 11-12).

Throughout the reign of James I, the English government had to deal frequently with problems that emerged from the Anglo-Dutch competition in the fishing industries. Both James and Parliament took steps to encourage English fishing. No less than five different conferences between the two countries discussed the issue of sovereignty and fishing rights. The English correctly realized that the Dutch fishing industry provided a large measure of Dutch prosperity but found it particularly nettlesome that the source of this affluence arose from fishing grounds in English waters. James's attempt to require Dutch and other foreign fishermen to purchase a license to fish in English waters failed. But during James's reign, Anglo-Dutch relations in the fishing trade shifted from English acceptance of Dutch fishing in English waters to open rivalry.

\section{Works Cited}

Alsop, J. D. "William Welwood, Anne of Denmark and the Sovereignty of the Seas.” Scottish Historical Review 59 (1980): 1714.

Clark, G. N. and Van Eysinga Jonkheer W. J. M. The Colonial Conferences between England and the Netherlands in 1613 and 1615, Part II. Leiden: E. J. Brill, 1951.

Dictionary of National Biography. Cited as D.N.B.

Edmundson, George. Anglo-Dutch Rivalry during the First Half of the Seventeenth Century. Oxford: The Clarendon Press, 1911. Elder, John R. The Royal Fishery Companies of the Seventeenth Century. Glasgow: James Maclehose and Sons, 1912.

Gentleman, Tobias. England's Way to Win Wealth and to Employ Ships and Mariners. London, 1614.

Kayall, Robert. The Trades Increase. London: Printed by Nicholas Oakes, 1615.

Larkin, James P. and Hughes Paul, eds. Stuart Royal Proclamations, Vol. 1, Royal Proclamations of King James I, 1603-1625. Oxford: The Clarendon Press, 1973.

McCulloch, John R. A Select Collection of Scarce and Valuable Tracts on Commerce. London, 1859, Reprint, New York: Augustus M. Kelley, 1966.

Parker, Geoffrey. Spain and the Netherlands, 1559-1659. London: William Collins, 1979.

Rich, E. E. and Wilson, C. H., eds. The Cambridge Economic History of Europe. Cambridge: Cambridge University Press, 1977.

Unger, Richard W. "Dutch Herring, Technology and International Trade in the Seventeenth Century.” Journal of Economic History 40 (1980): 254-67.

Winwood, Ralph and Sawyer Sir Edmund. Memorials of Affairs of State in the Reigns of Q. Elizabeth and K. James. London: Printed by W. B. for T. Ward, 1725.

Wilson, Charles H. The Dutch Republic and the Civilisation of the Seventeenth Century. New York: McGraw-Hill, 1968. 
Great Britain, Historical Manuscript Commission... (series)

The Manuscripts of the Marquis of Salisbury

Great Britain, Parliament...

(series)

Journals of the House of Lords

Great Britain, Privy Council... (series)

Acts of the Privy Council

Great Britain, Public Record Office... (series)

Calendar of State Papers, Venice

London, British Library, Department of Manuscripts. .

(series)

Lansdowne Manuscripts

London, Lambeth Palace Library... (series)

Archiepiscopal Manuscripts

London, Public Record Office...

Calendar of State Papers...

Domestic Series, of the Reign of Charles II

State Papers, Domestic, James I

State Papers, Foreign, Holland, James I

Scotland, General Register House

Register of the Privy Council of Scotland (short reference)

Salisbury

(short reference)

L.J.

(short reference)

$$
\text { A.P.C. }
$$

(short reference)

C.S.P. Venice

(short reference)

Lansdowne MSS

(short reference)

Arch. MSS

(short reference)

(short reference)

C.S.P. Charles II

S.P. $14 / .$.

S.P. $84 / \ldots$

(short reference)

R.P.C. Scotland 